\title{
Curcumin as a Natural Remedy for Atherosclerosis: A Pharmacological Review
}

\author{
Laxman Singh ${ }^{1}$, Shikha Sharma ${ }^{2}$, Suowen $\mathrm{Xu}^{3, * \mathbb{C}}$, Devesh Tewari ${ }^{2, * \mathbb{C}}$ and Jian Fang ${ }^{4, *}$ \\ 1 Centre of Biodiversity Conservation \& Management, G.B.Pant National Institute of Himalayan Environment, \\ Almora 263643, Uttarakhand, India; laxmansingh_13@yahoo.com \\ 2 School of Pharmaceutical Sciences, Lovely Professional University, Phagwara 144411, Punjab, India; \\ shikhasharma22012@gmail.com \\ 3 Department of Endocrinology, Division of Life Sciences and Medicine, The First Affiliated Hospital of USTC, \\ University of Science and Technology of China, Hefei 230037, China \\ 4 Department of Pharmacy, Huadu District People's Hospital, Southern Medical University, \\ Guangzhou 510800, China \\ * Correspondence: sxu1984@ustc.edu.cn (S.X.); dtewari3@gmail.com (D.T.); lifegz@163.com (J.F.)
}

Citation: Singh, L.; Sharma, S.; Xu, S.; Tewari, D.; Fang, J. Curcumin as a Natural Remedy for Atherosclerosis: A Pharmacological Review. Molecules 2021, 26, 4036. https://doi.org/ $10.3390 /$ molecules 26134036

Academic Editor: Assunta Pandolfi

Received: 29 March 2021

Accepted: 28 June 2021

Published: 1 July 2021

Publisher's Note: MDPI stays neutral with regard to jurisdictional claims in published maps and institutional affiliations.

Copyright: (C) 2021 by the authors Licensee MDPI, Basel, Switzerland. This article is an open access article distributed under the terms and conditions of the Creative Commons Attribution (CC BY) license (https:// creativecommons.org/licenses/by/ $4.0 /)$.

\begin{abstract}
Curcumin, a natural polyphenolic compound present in Curcuma longa L. rhizomes, shows potent antioxidant, anti-inflammatory, anti-cancer, and anti-atherosclerotic properties. Atherosclerosis is a comprehensive term for a series of degenerative and hyperplasic lesions such as thickening or sclerosis in large- and medium-sized arteries, causing decreased vascular-wall elasticity and lumen diameter. Atherosclerotic cerebro-cardiovascular disease has become a major concern for human health in recent years due to its clinical sequalae of strokes and heart attacks. Curcumin concoction treatment modulates several important signaling pathways related to cellular migration, proliferation, cholesterol homeostasis, inflammation, and gene transcription, among other relevant actions. Here, we provide an overview of curcumin in atherosclerosis prevention and disclose the underlying mechanisms of action of its anti-atherosclerotic effects.
\end{abstract}

Keywords: curcumin; atherosclerosis; pharmacology; therapeutics

\section{Introduction}

Atherosclerosis is a common cause of cerebro-cardiovascular disease and is an agerelated chronic large-artery condition that develops in adult and aged patients [1]. The pathogenesis of atherosclerosis is multifaceted. Numerous investigations have highlighted hyperlipidemia, diabetes, smoking, hypertension, and other cardiovascular risk factors which mediate oxidative stress causing damage to vascular endothelial cells. They also cause infiltration of low-density lipoproteins (LDL) into the sub-endothelial space, monocyte chemotaxis, aggregation below the endothelium, and platelet activation leading to chronic inflammatory responses in vascular walls [2-5]. Atherosclerosis is the pathological basis for many cerebro-cardiovascular diseases and acute cerebro-cardiovascular events such as myocardial infarction and ischemic stroke, making it a serious public health concern [6,7]. Anti-arteriosclerotic traditional Chinese medicines (TCM) are widely used in Chinese clinical practice with a good safety profile and lasting efficacy [8,9]. Many traditional medicines used in TCM and other traditional medicine systems such as Ayurveda including turmeric and ginseng have anti-atherosclerotic effects $[10,11]$.

Turmeric prepared from the dried rhizomes of Curcuma longa L. (family, Zingiberaceae) is enriched with multiple bioactive chemical entities with multiple therapeutic applications. The roots and rhizomes of turmeric contain curcumin that has been used as a traditional drug to increase blood circulation and improve stasis [12]. Curcumin has lipid-lowering, antioxidative, anti-inflammatory, and anti-infective effects [13-15]. There is growing evidence that curcumin can regulate different signaling molecules to retard the 
progression and development of atherosclerosis [16]. Similarly, curcumin is also known to regulate inflammatory responses by inhibiting nuclear factor kappa B (NF- $\mathrm{B}$ ) expression in atherosclerotic plaques of aortic walls in domestic rabbits and alleviate the severity of atherosclerosis [16].

The mechanistic function of curcumin against atherosclerosis is due at least in part to its anti-inflammatory and anti-oxidative effects and inhibition of vascular smooth muscle cell (VSMC) proliferation and migration. Firstly, inflammation is involved in the entire process of atherosclerosis [17]. According to previous research, curcumin affects inflammatory cells and factors such as inflammation-related enzymes to carry out its anti-inflammatory effects [18,19]. Likewise, curcumin blocks NF-kB signaling to diminish the production of vascular cell-adhesion molecules and inhibit interactions between leukocytes and endothelial cells [20]. Secondly, oxidative stress is a prominent hallmark phenomena that initiates the development of atherosclerosis [21]. Oxidized low-density lipoprotein (oxLDL) is the common link in various aspects of atherosclerosis [22]. Curcumin decreases the sensitivity of LDL towards oxidization, and thus decreases the load of oxidized product to interact with the oxidized low-density lipoprotein receptor 1 (LOX-1) [23]. Curcumin also down regulates inducible nitric oxide synthase activity to inhibit nitro-/oxidative-stress [24]. Thirdly, VSMC proliferation and migration of cells to the intima causes intimal thickening in atherosclerosis. Specifically, neointimal responses associated with artery damage cause proliferation, migration, and collagen synthesis in VSMCs that may increase the susceptibility of blood vessels towards atherosclerosis [25]. Curcumin can increase PPAR- $\gamma$ activity to inhibit the proliferation of VSMCs [26].

Additionally, epidemiological studies highlight that human cytomegalovirus (HCMV) infection is intimately coupled with the progression and development of atherosclerosis [27]. After entry, HCMV can damage vascular endothelial cells and alter their proliferation [28]. Oral administration of curcumin in $\mathrm{ApoE}^{-/-}$mice inhibits HCMV infection and improves the cellular microenvironment in the host, thereby effectively preventing the development of atherosclerotic lesions [29].

\section{Atheroprotective Effects of Curcumin In Vitro}

The potential of curcumin in protecting against various medical ailments, including atherosclerosis, has been widely assessed. Atherosclerosis is a chronic inflammatory disease resulting from arterial wall injury, sustained due to dyslipidemia, diabetes, hypertension, and other cardiovascular risk factors that leads to macrophage and VSMC-derived foam cell formation, endothelial cell dysfunction, immune cell activation, platelet activation, and thrombus formation [30-33]. Several studies have demonstrated curcumin's potent therapeutic potential in preventing foam cell formation, modulating macrophage polarization, tuning cholesterol efflux, and regulating pro-inflammatory responses [16,34-38].

The anti-atherosclerotic properties of curcumin are expressed through suppressing macrophage polarization (M1 to M2) [39] or by inducing M2 polarization via IL-4 and/or IL-13 secretion in macrophages [40]. Similarly, convincing evidence suggests that curcumin, when acting against macrophages treated with oxLDL, upregulates the expression of thrombospondin-4 (THBS-4) [36] and modulates chemoattractant protein-1 (MCP-1) expression, which represents the anti-inflammatory response [41]. The molecular targets of anti-atherosclerotic effects of curcumin involve upregulation of miR-126, which further inhibits signal transduction and PI3K/AKT and JAK2/STAT5 activation [42]. Other targets of curcumin include NF- $\mathrm{kB}$ inhibition in the M1 macrophages, as well as promoting M2 phenotype via PPAR- $\gamma$ activation. Further, curcumin inhibits toll-like receptor-4 (TLR4), MAPK, and NF-kB signaling in macrophages and VSMCs [43] (Table 1). 
Table 1. In vitro evidence supporting the therapeutic potential of curcumin against atherosclerosis.

\begin{tabular}{|c|c|c|c|}
\hline Experimental Model & $\begin{array}{l}\text { Concentration } \\
\text { Used }\end{array}$ & Outcomes and Possible Mechanisms of Action & References \\
\hline U937 monocytes & $0.01-1 \mu \mathrm{M}$ & $\begin{array}{l}\text { - Inhibit lipid peroxidation and inflammatory cytokine production } \\
\text { under high glucose stimulated conditions }\end{array}$ & {$[44]$} \\
\hline HMEC- 1 cells & $0.1-10 \mu \mathrm{M}$ & $\begin{array}{l}\text { - } \quad \text { Reduce cell migration and viability and repress MMP-2, MMP-9, } \\
\text { and VEGF expression } \\
\text { - Upregulate miR-126 expression and inhibit PI3K/AKT and } \\
\text { JAK2/STAT5 signal transduction }\end{array}$ & {$[42]$} \\
\hline $\begin{array}{l}\text { ANA-1 mouse } \\
\text { macrophage cell line }\end{array}$ & $5-25 \mu \mathrm{M}$ & - $\quad$ Decrease THBS-4 expression as induced by oxLDL & [36] \\
\hline $\begin{array}{l}\text { RAW } 264.7 \\
\text { macrophages }\end{array}$ & & $\begin{array}{l}\text { - Inhibit foam cell formation and CD36 expression level via } \\
\text { blocking p38 MAPK phosphorylation }\end{array}$ & [34] \\
\hline $\begin{array}{l}\mathrm{H} 9 \mathrm{c} 2 \text { rat cardiac } \\
\text { myoblasts }\end{array}$ & $5-40 \mu \mathrm{M}$ & $\begin{array}{ll}- & \text { Activate p38-MAPK and JNK signaling pathways } \\
\text { - } & \text { Promote apoptosis by chromatin condensation }\end{array}$ & [36] \\
\hline $\begin{array}{l}\text { Human monocytic } \\
\text { THP-1 cells }\end{array}$ & $7.5-30 \mu \mathrm{M}$ & $\begin{array}{l}\text { - Inhibit M1 macrophage polarization and cytokine production } \\
\text { (IL-6, IL-12B, and TNF- } \alpha \text { ) and decrease TLR-4 expression } \\
\text { - Inhibit ERK, JNK, p38, and NF-kB phosphorylation, exerting } \\
\text { anti-inflammatory and anti-atherosclerotic activity }\end{array}$ & [43] \\
\hline $\begin{array}{l}\text { Human monocytic } \\
\text { THP-1 cells }\end{array}$ & $5-20 \mu \mathrm{M}$ & $\begin{array}{ll}- & \text { Reduce the influx of oxLDL in THP-1 cells } \\
- & \text { Suppress CD36 and aP2 expression }\end{array}$ & [45] \\
\hline $\begin{array}{l}\text { RAW264.7 } \\
\text { macrophage }\end{array}$ & 6.25 and $12.5 \mu \mathrm{M}$ & $\begin{array}{l}\text { - Increase cholesterol efflux via Apo-A1 and HDL in macrophages } \\
\text { - } \quad \text { Reduce oxLDL-induced cytokine production as well as M1 } \\
\text { macrophage apoptosis } \\
\text { - } \quad \text { Upregulate CD36 and ABCA1 expression in M1 macrophages }\end{array}$ & [37] \\
\hline $\mathrm{Ba} / \mathrm{F} 3$ cells & $10-20 \mu \mathrm{M}$ & $\begin{array}{l}\text { - Inhibit TLR4 dimerization at the receptor level } \\
\text { - Inhibit the activation of MyD88 and TRIF-dependent pathways, } \\
\text { thereby blocking NF-KB and IRF3 signaling }\end{array}$ & [46] \\
\hline $\begin{array}{l}\text { RAW264.7 } \\
\text { macrophage }\end{array}$ & $6.25-25 \mu \mathrm{M}$ & $\begin{array}{l}\text { - Inhibit the expression of M1 macrophage markers (i.e., iNOS, } \\
\text { IL-1b, IL-6, and MCP-1) and upregulate IKB } \alpha \text { expression }\end{array}$ & [47] \\
\hline $\begin{array}{l}\text { RAW264.7 } \\
\text { macrophage }\end{array}$ & $6.25-50 \mu \mathrm{M}$ & $\begin{array}{l}\text { - Upregulate the expression of M2 markers such as MMR, Arg-1, } \\
\text { and PPAR-, as well as macrophage M2 polarization via IL-4 } \\
\text { and/or IL-13 secretion. }\end{array}$ & [40] \\
\hline $\begin{array}{l}\text { RAW264.7 } \\
\text { macrophage }\end{array}$ & 6.25 , and $25 \mathrm{nM}$ & $\begin{array}{l}\text { Repress titanium (Ti) particle-induced inflammation via } \\
\text { modulating macrophage M1 to M2 polarization }\end{array}$ & [34] \\
\hline $\begin{array}{l}\text { RAW264.7 } \\
\text { macrophage }\end{array}$ & $8-128 \mu \mathrm{M}$ & $\begin{array}{l}\text { - Inhibit lipid accumulation and the production of MCP-1, TNF- } \alpha \text {, } \\
\text { and IL-6 }\end{array}$ & [48] \\
\hline $\begin{array}{l}\text { Mouse peritoneal } \\
\text { macrophages }\end{array}$ & $10-50 \mu \mathrm{M}$ & - $\quad$ Reduce TLR4 expression and inhibit NF- $\kappa \mathrm{B}$ activation & [16] \\
\hline $\begin{array}{l}\text { Human monocytic } \\
\text { THP-1 cells }\end{array}$ & $20-40 \mu \mathrm{M}$ & $\begin{array}{l}\text { - Inhibit HIF-1 } \alpha \text {-induced apoptosis and inflammation of } \\
\text { macrophages via ERK signaling pathway }\end{array}$ & [49] \\
\hline $\begin{array}{l}\text { Bovine aortic } \\
\text { endothelial cells } \\
\text { (BAECs) }\end{array}$ & $5-15 \mu \mathrm{M}$ & $\begin{array}{l}\text { - Inhibit the expression of ET-1mRNA in BAECs, which may } \\
\text { influence the formation of atherosclerotic plaques }\end{array}$ & [50] \\
\hline
\end{tabular}


Table 1. Cont.

\begin{tabular}{|c|c|c|c|}
\hline Experimental Model & $\begin{array}{l}\text { Concentration } \\
\text { Used }\end{array}$ & Outcomes and Possible Mechanisms of Action & References \\
\hline $\begin{array}{l}\text { RAW264.7 } \\
\text { macrophage }\end{array}$ & $0.1-30 \mu \mathrm{M}$ & - $\quad$ Repress IL-1 $\beta$, IL- 6 , and TNF- $\alpha$ production & [51] \\
\hline $\begin{array}{l}\text { Human monocytic } \\
\text { THP-1 cells }\end{array}$ & $0-50 \mu \mathrm{M}$ & $\begin{array}{l}\text { - Attenuate MMP-9 and EMMPRIN expression via downregulation } \\
\text { of NF- } \mathrm{B} \text { and p38 MAPK signaling }\end{array}$ & [52] \\
\hline $\begin{array}{l}\text { Human monocytic } \\
\text { THP-1 cells }\end{array}$ & 0 to $100 \mu \mathrm{M}$ & $\begin{array}{l}\text { - Inhibit MMP-9 and EMMPRIN expression via inhibiting AMPK } \\
\text { and PKC pathway }\end{array}$ & [53] \\
\hline $\begin{array}{l}\text { Human monocytic } \\
\text { THP-1 cells }\end{array}$ & $10-20 \mu \mathrm{M}$ & $\begin{array}{l}\text { - Inhibit the PKC- } \delta / N A D P H \text { oxidase/ROS signaling and suppress } \\
\text { matrix invasion }\end{array}$ & {$[54]$} \\
\hline $\begin{array}{l}\text { Human monocytic } \\
\text { THP-1 cells }\end{array}$ & $0-50 \mu \mathrm{M}$ & $\begin{array}{l}\text { - Suppress TLR4/MyD88/NF- } \mathrm{KB} \text { and P2X7R signaling and inhibit } \\
\text { inflammasome activation }\end{array}$ & [55] \\
\hline $\begin{array}{l}\text { THP1-derived } \\
\text { macrophage foam cells }\end{array}$ & $0-80 \mu \mathrm{M}$ & $\begin{array}{l}\text { - Promote cholesterol efflux via increased ABCA1 expression via } \\
\text { AMPK-SIRT1-LXRa signaling pathway }\end{array}$ & [38] \\
\hline $\begin{array}{l}\text { Human monocytic } \\
\text { THP-1 cells }\end{array}$ & $5.0 \mu \mathrm{g} / \mathrm{mL}$ & $\begin{array}{l}\text { - Increase macrophage apoptosis, thus indicating a novel son } \\
\text { o-dynamic therapy for atherosclerosis }\end{array}$ & [56] \\
\hline VSMCs & $5-30 \mu \mathrm{M}$ & $\begin{array}{l}\text { - Suppress oxLDL induced MCP-1 expression via p38 MAPK and } \\
\text { NF- } \mathrm{KB} \text { signaling }\end{array}$ & [57] \\
\hline $\begin{array}{l}\text { H9c2 embryonic rat } \\
\text { heart derived cells }\end{array}$ & $5-15 \mu \mathrm{M}$ & $\begin{array}{l}\text { Enhance DOX-induced cells apoptosis via Bcl-2 repression and } \\
\text { increasing expression of caspase- } 8 \text { and }-9\end{array}$ & [58] \\
\hline VSMCs & $5-30 \mu \mathrm{M}$ & 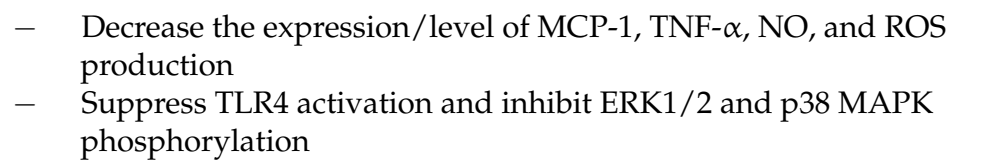 & [59] \\
\hline $\begin{array}{l}\text { RAW264.7 } \\
\text { macrophage }\end{array}$ & $0-40 \mu \mathrm{M}$ & $\begin{array}{l}\text { - Inhibit MCP-1 production via the JNK and NK- } \mathrm{B} B \text { signaling } \\
\text { - Enhance cholesterol efflux via activating the LXR- } \alpha, \mathrm{ABCA} 1 \text { and } \\
\text { SR-BI pathway }\end{array}$ & {$[60]$} \\
\hline 3T3-L1 fibroblast cells & $0-30 \mu \mathrm{M}$ & $\begin{array}{l}\text { - Inhibit MAPK phosphorylation by using Wnt/ } \beta \text {-catenin } \\
\text { signaling, which leads to 3T3-L1 cell differentiation into } \\
\text { adipocytes }\end{array}$ & [61] \\
\hline VSMCs & $1.25-5 \mu \mathrm{M}$ & $\begin{array}{l}\text { Inhibit CRP protein production by modulating ROS-ERK1/2 } \\
\text { signaling }\end{array}$ & [62] \\
\hline Endothelial cells & $10^{-5} \mathrm{M}$ & $\begin{array}{l}\text { - Inhibit CD40 expression and inflammatory activity via } \\
\text { miR-590-3p-dependent pathway }\end{array}$ & [63] \\
\hline $\begin{array}{l}\text { Cultured porcine } \\
\text { coronary artery rings }\end{array}$ & $5 \mu \mathrm{M}$ & $\begin{array}{l}\text { Block superoxide anion production mediated by eNOS } \\
\text { downregulation and reverse endothelial dysfunction }\end{array}$ & {$[64]$} \\
\hline HUVEC cells & $1,10,100 \mu \mathrm{M}$ & $\begin{array}{l}\text { - } \quad \text { Reduce E- and P-selectins expression and monocytes adhesion } \\
\text { induced by PM10 }\left(3 \mu \mathrm{g} / \mathrm{cm}^{2}\right) \text { and TiO2-NPs }\left(10 \mu \mathrm{g} / \mathrm{cm}^{2}\right) \\
\text { - } \\
\text { Attenuate oxidative stress activation induced by PM10 particles } \\
\text { and TiO2-NPs in endothelial cells }\end{array}$ & {$[65]$} \\
\hline
\end{tabular}


Table 1. Cont.

\begin{tabular}{|c|c|c|c|}
\hline Experimental Model & $\begin{array}{l}\text { Concentration } \\
\text { Used }\end{array}$ & Outcomes and Possible Mechanisms of Action & References \\
\hline HUVEC cells & $25 \mu \mathrm{M}$ & $\begin{array}{ll}- & \text { Inhibit COX-2 expression and prostaglandin production } \\
- & \text { Inhibit phosphorylation of PKC, p38 MAPK, and cAMP response } \\
\text { triggering COX-2 expression }\end{array}$ & [66] \\
\hline HUVEC cells & $1-25 \mu \mathrm{M}$ & $\begin{array}{l}\text { - Suppress the expression profile of ROS species, LOX-1 receptor, } \\
\text { and adhesion molecules (VCAM-1 and ICAM-1) } \\
\text { - } \quad \text { Inhibit I } \mathrm{B} \alpha \alpha \text { degradation and NFKB nuclear translocation }\end{array}$ & [67] \\
\hline HUVEC cells & $2.5-100 \mu \mathrm{M}$ & $\begin{array}{l}\text { - Decrease TLR2 and TLR4 mediated inflammatory response } \\
\text { - } \quad \text { Inhibit adhesion molecules expression that reconcile monocyte } \\
\text { adhesion and endothelial migration }\end{array}$ & [68] \\
\hline HUVEC cells & $3-30 \mu \mathrm{M}$ & $\begin{array}{ll}\text { - } & \text { Inhibit NF- } \mathrm{B} \text { activation via TNF- } \alpha \\
- & \text { Suppress intracellular ROS production, monocyte adhesion, and } \\
\text { JNK, p38, and STAT-3 phosphorylation } \\
\text { - } \quad \text { Attenuate expression profile of ICAM-1, MCP-1, and IL - } 8 \text { at both } \\
\text { mRNA and protein levels }\end{array}$ & [69] \\
\hline VSMCs & $20-40 \mu \mathrm{M}$ & $\begin{array}{l}\text { - Diminish phosphorylation of } \mathrm{p}-\mathrm{RhoA} / \mathrm{p}-\mathrm{MEK} 1 / 2 \text { and NF- } \mathrm{kB} \\
\text { signaling }\end{array}$ & [70] \\
\hline VSMCs & - & $\begin{array}{l}\text { - Activate miR-22/SP1 signaling pathway and prevent } \\
\text { proliferation and migration of VSMCs }\end{array}$ & [71] \\
\hline VSMCs & $12.5-50 \mu \mathrm{M}$ & $\begin{array}{l}\text { Inhibit cholesterol accumulation via activating caveolin-1 } \\
\text { expression that in turn negatively regulates SREBP-1 and } \\
\text { prevents nuclear translocation }\end{array}$ & [72] \\
\hline HUVEC cells & $0.5-2 \mu \mathrm{M}$ & $\begin{array}{ll}- & \text { Inhibit HCMV replication and proliferation } \\
- & \text { Reduce intracellular ROS production and diminish inflammatory } \\
\text { cytokine production } \\
\text { - }\end{array}$ & [29] \\
\hline VSMCs & $10-20 \mu \mathrm{M}$ & $\begin{array}{ll}- & \text { Reduce NO production by inhibiting IL- } 6 \text { and TNF-expression } \\
- & \text { Upregulate PPAR- } \gamma \text { activity and attenuate VSMC proliferation }\end{array}$ & [34] \\
\hline VSMCs & $20 \mu \mathrm{M}$ & $\begin{array}{l}\text { - Inhibit cell migration by negatively regulating NLRP3 expression } \\
\text { via NF- } \mathrm{B} \text {-mediated response and reduce IL-1 } \beta \text { concentration }\end{array}$ & [26] \\
\hline
\end{tabular}

HMEC-1, human micro-vascular endothelial; PARP, poly(ADP-ribose) polymerase;MMR, macrophage mannose receptor; Arg-1, arginase-1; HIF- $1 \alpha$, hypoxia- inducible factor $1 \alpha$; TGF- $\beta$, transforming growth factor beta; AMPK, AMP-activated protein kinase; PKC, protein kinase C; DOX, doxorubicin; ET-1, endothelin-1; PAR- $\gamma$, proliferator-activated receptor $\gamma$; LXR- $\alpha$, liver X receptor $\alpha$; SR-BI, scavenger receptor class B type I; JAKs, Janus activated kinases; iNOS, inducible nitric oxide synthase; MyD88, myeloid differentiation factor 88; P2X7R, purinergic 2 X7 receptor; PKC, protein kinase C; AD, aldosterone, CRP, C-reactive protein; HUVEC, human umbilical vein endothelial cells; LOX-1, lectin-like oxidized LDL receptor-1; TEM, trans-endothelial migration; HMGB1, high mobility group box-1; MEK 1/2, mitogen-activated protein kinase kinase 1/2; JNK-c, Jun N-terminal Kinase.

TLR4, an important signaling receptor, plays an important role in the pathogenesis of plaque formation and the development of atherosclerosis [73]. Furthermore, TLR4 activates a variety of signal transduction molecules as well as transcription factors. An important response of TLR4 activation is NF- $\mathrm{KB}$ and MAPK activation, which triggers nuclear transduction that simultaneously propels the gene expression profile of an inflammatory reaction. The amplified expression profile increases ROS production and the expression of inflammatory molecules, which causes the initiation of atherogenesis, leading ultimately to the clinically critical destabilization of atherosclerotic plaques [16]. Reports on curcumin supplementation fostering negative regulation not only on towards the TLR 
receptor but also on nuclear transduction molecules and inflammatory cytokines (TNF- $\alpha$, IL-1 $\beta$, VCAM-1, ICAM 1, etc.) are presented [74] (Figure 1).

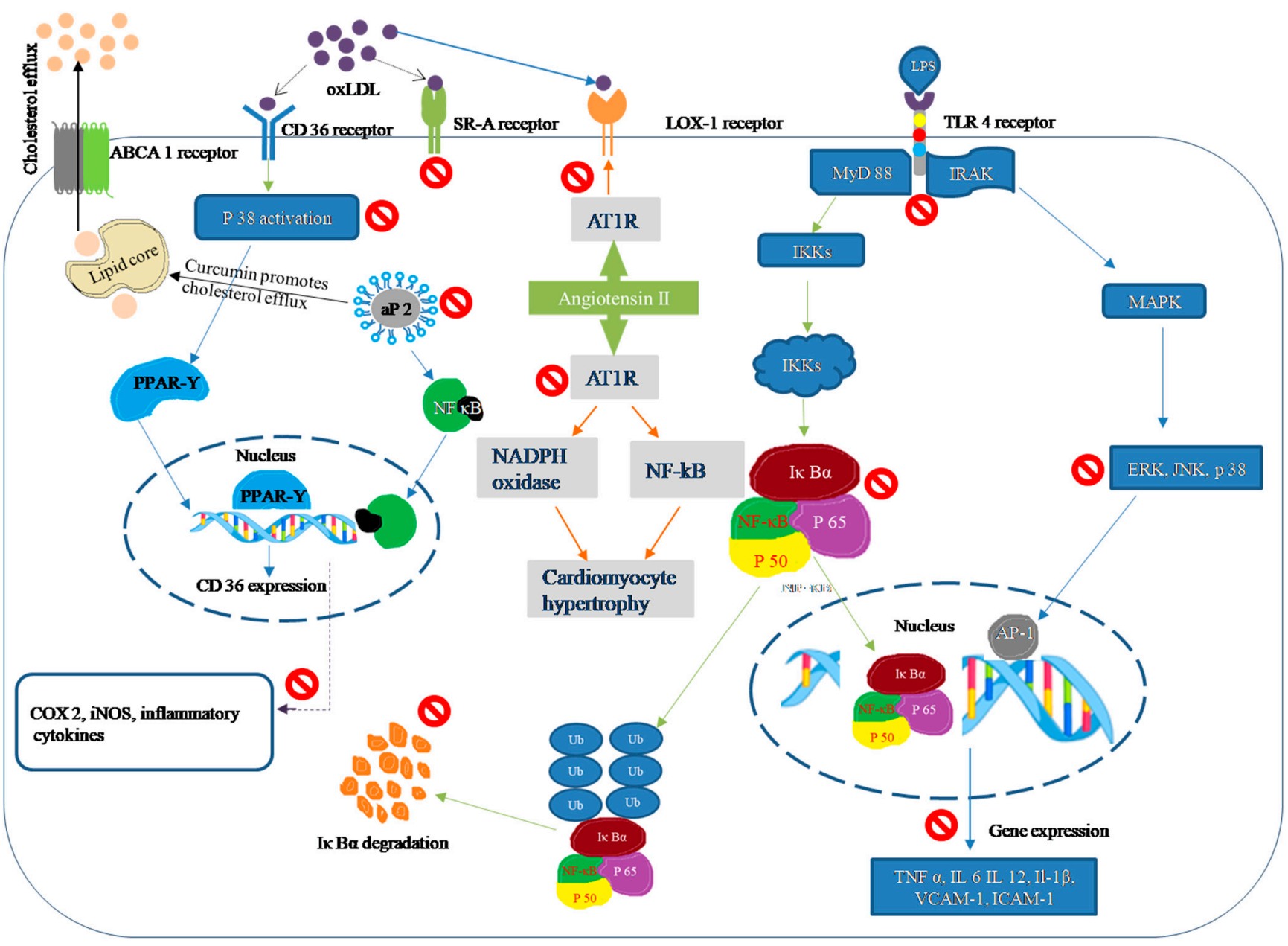

Figure 1. Pharmacological effects and mechanism of action of curcumin in atherosclerosis.

Curcumin has also been shown to inhibit ligand-induced and ligand-independent dimerization at the receptor level. LPS induces activation of both MyD88 and TRIFdependent signaling via the TLR4 receptor. Upon curcumin supplementation, TLR4 homodimerization was blocked [46], providing a novel mechanism for its anti-inflammatory effects. In a similar fashion, curcumin inhibits the NOD-like receptor (NLR) family, the pyrin domain containing 3 (NLRP3) inflammasome via suppressing TLR4/MyD88/NF-KB, the phosphorylation level of IkB- $\alpha$, and purinergic 2 X7 receptor (P2X7R) pathways in phorbol 12-myristate 13-acetate (PMA)-induced macrophages [55]. NLRP3 inflammasome is composed of a multiprotein complex having caspase and caspase 1 protein complex for apoptosis [75]. On NLRP3 complex stimulation, caspase-1 is activated, which cleaves the pro-forms of interleukin (IL)-1 $\beta$ and IL-18 into their mature forms. Once in fully mature form, IL-1 $\beta$ (a primary pro-inflammatory cytokine) mediates the development of atherosclerosis. Curcumin also inhibits VSMC migration by negatively regulating NLRP3 expression via an NF-kB-mediated response and decreasing IL-1 concentration [55].

In VSMCs, curcumin supplementation markedly reduces inflammatory responses induced by LPS acting at TLR4. LPS induced stimulation of TRL4 increases the phosphorylation of I $\mathrm{kB} \alpha, \mathrm{NF}-\kappa \mathrm{B}$ (p65), and MAPKs [59]. Concurrently, this increases the inflammatory cytokine expression profile of TLR4, MCP-1, iNOS, TNF- $\alpha$, and NO production. In addition, Meng et al. (2013) [59] established that curcumin supplementation inhibits TLR4 activation and ERK1/2 and p38 MAPK phosphorylation, thereby preventing NF- $\mathrm{KB}$ nuclear translo- 
cation that mediates ROS production. Thus, inhibition of the expression profile may reduce atherosclerotic plaque formation and reduce inflammatory cell infiltration into the plaques. More recently, Zhang et al. [62] showed that curcumin inhibits aldosterone-induced production of CRP in VSMCs by reducing ROS production via limiting aberrant activation of the ERK1/2 signal pathway.

LDL is another important pathological entity that contributes to the development of atherosclerotic lesions. ROS modifies LDL, thereby producing Ox-LDL. An increase in Ox-LDL concentration in plasma has long been recognized as a key factor in atherosclerosis. Ox-LDL, rather than binding to LDL receptor, binds to scavenger receptors (SRs). The major SR is CD36 that recognizes ox-LDL [76]. After binding to CD36 on cell membrane, ox-LDL can also trigger CD36 expression via PPAR- $\gamma$ pathway [77]. Specifically, PPAR- $\gamma$, once activated, dimerizes with the retinoid $X$ receptor $(R X R)$ and triggers PPAR-response element (PPRE)-containing genes, which ultimately increases CD36 expression, resulting in increased ox-LDL influx [78].

Cholesterol accumulation in macrophages results in foam cell formation and fatty streak development via upregulating the expression/activity of several receptors, such as SR-AI/II, SRBI, CD36, and LOX-1. In contrast, various efflux transporters play an active role via ATP-binding cassette $(\mathrm{ABC})$ transporters ABCA1, ABCG1, and SR-BI to facilitate reverse cholesterol transport from macrophages [79]. Fatty acid-binding protein (FABP)-4 or adipocyte protein 2 (aP2) coordinates cholesterol trafficking (efflux) but is also known to activate an inflammatory response. Lack of aP2 protein complex changes the cholesterol composition in macrophages, which concurrently amplifies CD36 expression and enhances oxLDL influx [80]. This cascade creates a disease state, whereby macrophages induce the release of IL-1 $\beta, \mathrm{TNF} \alpha, \mathrm{ROS}$, and matrix metalloproteases coupled with the development of inflammation, cell migration, and plaque formation (Figure 1). Hence, genetic or pharmacological inhibition of aP2 and CD36 expression might offer potential remedies to atherosclerosis.

Several further lines of experimental evidence highlight the potent anti-atherogenic effects of curcumin (documented in Table 1). For example, Zhou et al. (2014) [36] demonstrated that curcumin treatment reduces the expression profile of oxLDL-induced thrombospondins-4 (THBS-4). THBS-4 was reported to influence important cellular responses such as cell migration, proliferation, and adhesion, leading to atherogenesis progression [81]. Curcumin further inhibits p38 MAPK activation and reduces PPAR- $\gamma$ and CD36 expression in oxLDL-treated macrophages, leading to decreased foam cell formation [77]. In human umbilical vein endothelial cells (HUVECs), curcumin inhibits ROS production, NF- $\mathrm{KB}$-dependent LOX-1 expression, and VCAM-1 and ICAM-1 expression. In addition, curcumin promotes NO production to confer vasodilatory effects [6,7]. Recent studies also suggest that curcumin could reduce oxidative stress, ER stress, and inflammatory response induced by acrolein (a toxin from tobacco smoke) and cytomegalovirus (CMV) infection in human endothelial cells $[29,66]$. The anti-inflammatory effects of curcumin is exerted through inhibiting COX-2 expression and prostaglandin production via reducing the phosphorylation of PKC, p38 MAPK, and cAMP response element-binding protein as well as inhibiting the HMGB1-TLRS-NF- $\kappa B$ signaling pathway $[29,66]$. The broad anti-inflammatory effects of curcumin underlie its effects on improving flow-mediated dilation in human subjects [82].

\section{Atheroprotective Effects of Curcumin In Vivo}

Numerous lines of experimental evidence (Table 2) support the actions of curcumin in reducing the cardiovascular risk associated with atherosclerosis. 
Table 2. In Vivoevaluation of the pharmacological properties of curcumin against atherosclerosis.

\begin{tabular}{|c|c|c|c|}
\hline $\begin{array}{l}\text { In Vivo Experimental } \\
\text { Model }\end{array}$ & $\begin{array}{c}\text { Curcumin } \\
\text { Concentration }\end{array}$ & Outcomes and Possible Mechanisms of Action & References \\
\hline $\mathrm{ApoE}^{-} /^{-}$mice & $0.1 \% w / w$ & 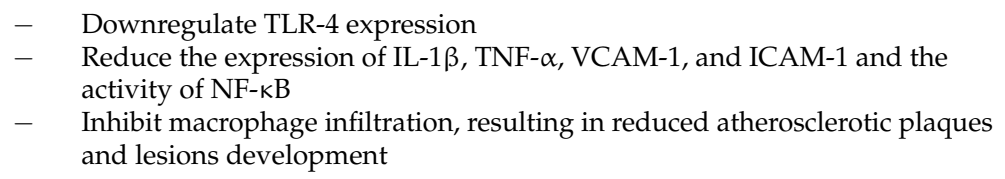 & [16] \\
\hline $\begin{array}{l}\text { Male New-Zealand } \\
\text { rabbits }\end{array}$ & $\begin{array}{l}1.66 \mathrm{mg} / \mathrm{kg} \text { body } \\
\text { weight }\end{array}$ & $\begin{array}{ll}- & \text { Reduce LDL propensity to lipid peroxidation } \\
- & \text { Decrease TC, TG, and phospholipids level in rabbits }\end{array}$ & [10] \\
\hline $\begin{array}{l}\text { New Zealand white } \\
\text { male rabbits }\end{array}$ & $10 \mathrm{mg} / \mathrm{kg} /$ week & $\begin{array}{l}-\quad \text { Reduce serum levels of TC, TG, and LDL-c } \\
-\quad \text { Decrease atherosclerotic lesions in the aortic arch }\end{array}$ & [35] \\
\hline Ldlr $^{-} /^{-}$mice & $500-1500 \mathrm{mg} / \mathrm{kg}$ & $\begin{array}{ll}- & \text { Reduce oxLDL uptake in HP-1 cells } \\
- & \text { Reduce the formation of fatty streaks and inhibit the expression of } \\
\text { inflammatory cytokines, aP2, and CD36 } \\
-\quad \text { Repress the progression of steatohepatosis }\end{array}$ & [45] \\
\hline Male Wistar rats & $\begin{array}{l}100 \mathrm{mg} /(\mathrm{kg} / \mathrm{d}) \\
\text { curcumin }\end{array}$ & $\begin{array}{l}\text { - Inhibit the expression profile of MMP-9, CD40L, TNF- } \alpha \text {, and CRP, thereby } \\
\text { improving the permeability of coronary artery }\end{array}$ & [83] \\
\hline ApoE ${ }^{-} /^{-}$mice & $200 \mathrm{mg} / \mathrm{kg} / \mathrm{d}$ & $\begin{array}{l}\text { - Modulate T helper cell (Th2) and regulatory T cells (Tregs) to recover the } \\
\text { formed atherosclerotic lesions and plaque }\end{array}$ & [84] \\
\hline Male Rabbits & $0.2 \%$ & $\begin{array}{l}\text { - Reduce the expression of CRP, ICAM1, VCAM1, and PCSK9 gene } \\
\text { expression }\end{array}$ & [85] \\
\hline $\begin{array}{l}\text { ApoE/LDLR- } \\
\text { doubleknockout } \\
\text { mice }\end{array}$ & $0.3 \mathrm{mg} /$ perday & $\begin{array}{ll}- & \text { Reduce TC and TG levels in blood } \\
- & \text { Reduce atherosclerotic lesion area and size }\end{array}$ & [20] \\
\hline $\begin{array}{l}\text { Male C57BL/6J (B6) } \\
\text { mice }\end{array}$ & $0.09 \mathrm{mg}$ & $\begin{array}{l}\text { - Prevent liver fat accumulation and development of atherosclerotic lesions } \\
\text { - } \quad \text { Improve hyperlipidemia state }\end{array}$ & [86] \\
\hline $\mathrm{ApoE}^{-} /^{-}$mice & $0.2 \%$ & - $\quad$ Reduce leukocyte adhesion and trans endothelial migration & [87] \\
\hline $\mathrm{LDLR}^{-} /^{-}$mice & $100 \mathrm{mg} / \mathrm{kg}$ & $\begin{array}{l}\text { - Improve intestinal function against glucose intolerance } \\
\text { - } \quad \text { Reduce aortic lesion area }\end{array}$ & [88] \\
\hline Sprague-Dawley rats & $\begin{array}{l}100 \mathrm{mg} / \mathrm{kg} \text { body } \\
\text { weight }\end{array}$ & $\begin{array}{l}\text { - Inhibit the production of IL- } 6 \text {, TNF- } \alpha \text {, IL-8, MCP-1, glucose, and } \\
\text { glycosylated hemoglobin }\left(\mathrm{HbA}_{1}\right)\end{array}$ & [44] \\
\hline Sprague-Dawley rats & $0.2-5.0 \mathrm{mg} / \mathrm{kg}$ & - Inhibit the production of TNF- $\alpha$, IL- $1 \beta$, and MCP- 1 & [89] \\
\hline Zebrafish & $10 \% \mathrm{wt} / \mathrm{wt}$ & - Inhibit hyper cholesterolemic state and improve antioxidant activity & [90] \\
\hline $\mathrm{ApoE}^{-} /^{-}$mice & $15-25 \mathrm{mg} / \mathrm{kg} / \mathrm{d}$ & 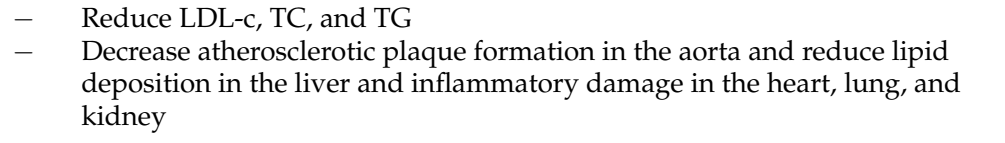 & [29] \\
\hline ApoE $/^{-}$mice & $10 \mathrm{mg} / \mathrm{kg}$ & $\begin{array}{l}\text { - Reduce the formation of microvessel plaques, inhibit MMP-2 and -9 activity } \\
\text { and regulate LDL-c metabolism }\end{array}$ & [59] \\
\hline $\mathrm{LDLR}^{-} /^{-}$mice & $0.02 \% w / w$ & $\begin{array}{ll}- & \text { Decrease TC, TG, LDL-C, and Apo-B levels } \\
- & \text { Increase plasma HDL-c and liver Apo A-I expression } \\
- & \text { Inhibit HMG-CoA reductase, ACAT1, and ACAT2 expression }\end{array}$ & [91] \\
\hline ApoE $/^{-}$mice & $\begin{array}{l}40,60, \text { and } 80 \\
\mathrm{mg} / \mathrm{kg} / \mathrm{d} \\
\text { curcumin }\end{array}$ & $\begin{array}{l}\text { - Reduce lipocalin-2 (LCN2) biomarkers of atherosclerosis, present an } \\
\text { anti-hyperlipidemic effect, and inhibit the inflammatory response }\end{array}$ & [92] \\
\hline Male ICR mice & $1-2 \mathrm{mmol} / \mathrm{kg} /$ day & $\begin{array}{l}\text { - Ameliorate dyslipidemia and hyperglycemia, reduce oxidative stress, and } \\
\text { enhance antioxidant activity }\end{array}$ & [93] \\
\hline ApoE $/^{-}$mice & $0.1 \% w / w$ & $\begin{array}{ll}- & \text { Reduce TC accumulation in the aortas } \\
- & \text { Lower LDL-c level and decrease intestinal cholesterol absorption }\end{array}$ & [94] \\
\hline
\end{tabular}

VCAM-1, vascular cell adhesion molecule; ICAM-1, intracellular adhesion molecule; MMP, matrix metalloproteinase; Apo A-I, apolipoprotein A-I; Apo B, apolipoprotein B; HMG-CoA, 3-hydroxy-3-methyl-glutaryl-co-enzyme A reductase; ACAT, acyl-CoA/cholesterol acetyl transferases; TC, total cholesterol; TG, triglyceride; LDL-C, low-density lipoprotein cholesterol; HDL-C, high density lipoprotein cholesterol; $\mathrm{CRP}$-creactive protein; MCP 1, monocyte chemoattractant protein 1. 


\section{Clinical Studies of Curcumin}

Few clinical trials involving double-blind placebo-controlled studies and randomized controlled trials have been undertaken. A 12-week randomized placebo-controlled trial of 118 participants showed that curcumin treatment reduced the risk of developing acute cardiovascular events in people with type 2 diabetes and dyslipidemia [95]. Another randomized controlled research with 87 patients found that taking $1 \mathrm{~g}$ of curcumin for eight weeks lowered TC, TG, and HDL-c levels following nonalcoholic fatty liver infections [96]. On the other hand, curcumin lowered LDL-c and Apo B and increased Apo A1 and HDL-c levels in healthy people, indicating anti-atherosclerosis efficacy [97]. In coronary bypass graft, curcumin ( $4 \mathrm{~g} /$ day) reduced acute myocardial infarction and significantly decreased malondialdehyde levels [98]. Further, in patients with chronic obstructive pulmonary disease, curcumin (Theracurmin ${ }^{\circledR} 90 \mathrm{mg}$ /day for 24 weeks) reduced the level of the $\alpha 1$-antitrypsin-low-density lipoprotein (AT-LDL) complex, which promotes arteriosclerosis [99]. In another randomized trial, curcumin usage at $80 \mathrm{mg}$ per day ameliorated dyslipidemia in patients with reduced serum TG, salivary amylase, and $\beta$-amyloid levels and increased plasma nitric oxide level after four weeks of study [100]. Likewise, in a double-blind placebo-controlled study, curcumin $(200 \mathrm{mg})$ supplementation improved endothelial function measured by flow-mediated dilation (FMD), thus decreasing the risk of cardiovascular diseases [101]. In another pilot study, curcumin $(500 \mathrm{mg} /$ day for 12 weeks) de-stiffened arteries in young, obese men with aortic stiffness [102]. Studies with curcumin have potential limitations due to factors such as limited sample sizes; therefore, large-scale clinical trials are required to characterize the actual potential and identify the direct molecular targets of curcumin in treating atherosclerosis.

\section{Conclusions and Perspectives}

Substantial experimental evidence suggests that curcumin prevents endothelial dysfunction, smooth muscle cell proliferation and migration, and foam cell formation and modulates macrophage polarization. Curcumin also counteracts inflammatory response, supporting its potential application in atherosclerosis treatment. The anti-atherosclerotic properties of curcumin occur through suppressing inflammatory response by skewing macrophage polarization from M1 to M2 or by inducing M2 polarization through regulating TLR4/MAPK/NF- $\mathrm{kB}$ pathways in macrophages and secretion of interleukins (IL-4 and /or IL-13). Similarly, curcumin concurrently regulates the expression and activity of the lipid transporter expression (CD36, CD38, $\mathrm{ABCA1}$, aP2, etc.) responsible for cholesterol uptake and efflux, thus maintaining cell homeostasis. In addition, curcumin lowers the circulating level of ox-LDL and blocks oxLDL elicited pro-atherogenic events by decreasing the expression of MCP-1 and THBS- 4 via the p38 MAPK and NF- $\mathrm{kB}$ pathways [52]. Likewise, curcumin suppresses TLR4 expression and macrophage infiltration in aortic tissues and protects against atherosclerotic plaque formation [16]. A recent study has suggested that curcumin blocks LPA-induced MCP-1 expression via TGFBR1/ROCK signaling pathway [103].Additional studies are required to improve or add meaningful insights into our understanding of the mechanism(s) of action of curcumin against atherosclerosis, especially in the clinical setting. In addition, the development of novel drug delivery systems, such as the creation of curcumin nanomicelles [104,105], is critical for improving the oral bioavailability of curcumin which may contribute to its clinical efficacy [106].

Author Contributions: Conceptualization, S.X., D.T. and J.F.; data curation, L.S., S.S. and D.T.; writing-original draft preparation, L.S., J.F. and D.T.; writing-review and editing, S.X., D.T. and J.F.; supervision, S.X.; funding acquisition, S.X. All authors have read and agreed to the published version of the manuscript.

Funding: This study was partially supported by grants from Natural Science Foundation of China (No. 82070464).

Acknowledgments: D.T. and S.S. express their gratitude towards Management, Senior Dean and CoD of Lovely Professional University, Punjab, India for providing necessary facilities and time to 
conduct the study. The authors are grateful to Peter J. Little (University of Sunshine Coast, Australia) for proofreading and editing of the manuscript.

Conflicts of Interest: The authors declare no conflict of interest.

\section{References}

1. Hannawi, S.; Hannawi, H.; Al Salmi, I. Cardiovascular disease and subclinical atherosclerosis in rheumatoid arthritis. Hypertens. Res. 2020, 43, 982-984. [CrossRef] [PubMed]

2. Bi, C.; Fu, Y.; Li, B. Brain-derived neurotrophic factor alleviates diabetes mellitus-accelerated atherosclerosis by promoting M2 polarization of macrophages through repressing the STAT3 pathway. Cell. Signal. 2020, 70, 109569. [CrossRef]

3. Ito, K.; Maeda, T.; Tada, K.; Takahashi, K.; Yasuno, T.; Masutani, K.; Mukoubara, S.; Arima, H.; Nakashima, H. The role of cigarette smoking on new-onset of chronic kidney disease in a Japanese population without prior chronic kidney disease: Iki epidemiological study of atherosclerosis and chronic kidney disease (ISSA-CKD). Clin. Exp. Nephrol. 2020, 24, 919-926. [CrossRef] [PubMed]

4. Miao, J.; Zang, X.; Cui, X.; Zhang, J. Autophagy, Hyperlipidemia, and Atherosclerosis. Adv. Exp. Med. Biol. 2020, 1207, 237-264. [CrossRef] [PubMed]

5. Ye, J.; Wang, Y.; Wang, Z.; Liu, L.; Yang, Z.; Wang, M.; Xu, Y.; Ye, D.; Zhang, J.; Zhou, Q.; et al. The Expression of IL-12 Family Members in Patients with Hypertension and Its Association with the Occurrence of Carotid Atherosclerosis. Mediat. Inflamm. 2020, 2020, 2369279. [CrossRef]

6. Ntaios, G.; Pearce, L.A.; Meseguer, E.; Endres, M.; Amarenco, P.; Ozturk, S.; Lang, W.; Bornstein, N.M.; Molina, C.A.; Pagola, J.; et al. Aortic Arch Atherosclerosis in Patients with Embolic Stroke of Undetermined Source: An Exploratory Analysis of the NAVIGATE ESUS Trial. Stroke 2019, 50, 3184-3190. [CrossRef]

7. Pomozova, T.P.; Lykov, Y.V.; Komarova, I.S.; Dyatlov, N.V.; Zhelnov, V.V. Clinical and laboratory features of primary acute myocardial infarction in patients with obstructive and non-obstructive coronary atherosclerosis. Kardiologiia 2019, 59, 41-51. [CrossRef] [PubMed]

8. Kim, S.H.; Park, K.S. Effects of Panax ginseng extract on lipid metabolism in humans. Pharmacol. Res. 2003, 48, 511-513. [CrossRef]

9. Liu, J.; Zhang, J.; Shi, Y.; Grimsgaard, S.; Alraek, T.; Fønnebø, V. Chinese red yeast rice (Monascus purpureus) for primary hyperlipidemia: A meta-analysis of randomized controlled trials. Chin. Med. 2006, 1, 1-13. [CrossRef]

10. Ramírez-Tortosa, M.C.; Mesa, M.D.; Aguilera, M.C.; Quiles, J.L.; Baró, L.; Ramirez-Tortosa, C.L.; Martinez-Victoria, E.; Gil, A. Oral administration of a turmeric extract inhibits LDL oxidation and has hypocholesterolemic effects in rabbits with experimental atherosclerosis. Atherosclerosis 1999, 147, 371-378. [CrossRef]

11. Chan, G.H.-H.; Law, B.Y.-K.; Chu, J.M.-T.; Yue, K.K.-M.; Jiang, Z.-H.; Lau, C.-W.; Huang, Y.; Chan, S.-W.; Ying-Kit, Y.P.; Wong, R.N.S. Ginseng extracts restore high-glucose induced vascular dysfunctions by altering triglyceride metabolism and downregulation of atherosclerosis-related genes. Evid. Based. Complement. Altern. Med. 2013, 2013, 797310. [CrossRef] [PubMed]

12. Kim, J.H.; Yang, H.J.; Kim, Y.J.; Park, S.; Lee, O.H.; Kim, K.S.; Kim, M.J. Korean turmeric is effective for dyslipidemia in human intervention study. J. Ethn. Foods 2016, 3, 213-221. [CrossRef]

13. González-Ortega, L.A.; Acosta-Osorio, A.A.; Grube-Pagola, P.; Palmeros-Exsome, C.; Cano-Sarmiento, C.; García-Varela, R.; García, H.S. Anti-inflammatory Activity of Curcumin in Gel Carriers on Mice with Atrial Edema. J. Oleo Sci. 2020, 69, 123-131. [CrossRef] [PubMed]

14. Qin, S.; Huang, L.; Gong, J.; Shen, S.; Huang, J.; Ren, H.; Hu, H. Efficacy and safety of turmeric and curcumin in lowering blood lipid levels in patients with cardiovascular risk factors: A meta-analysis of randomized controlled trials. Nutr. J. 2017, 16, 68. [CrossRef] [PubMed]

15. Song, H.-C.; Chen, Y.; Chen, Y.; Park, J.; Zheng, M.; Surh, Y.-J.; Kim, U.-H.; Park, J.W.; Yu, R.; Chung, H.T.; et al. GSK-3ß inhibition by curcumin mitigates amyloidogenesis via TFEB activation and anti-oxidative activity in human neuroblastoma cells. Free Radic. Res. 2020, 1-13. [CrossRef]

16. Zhang, S.; Zou, J.; Li, P.; Zheng, X.; Feng, D. Curcumin Protects against Atherosclerosis in Apolipoprotein E-Knockout Mice by Inhibiting Toll-like Receptor 4 Expression. J. Agric. Food Chem. 2018, 66, 449-456. [CrossRef] [PubMed]

17. Marchio, P.; Guerra-Ojeda, S.; Vila, J.M.; Aldasoro, M.; Victor, V.M.; Mauricio, M.D. Targeting Early Atherosclerosis: A Focus on Oxidative Stress and Inflammation. Oxidative Med. Cell. Longev. 2019, 1, 32. [CrossRef]

18. Chen, Y.-Q.; Chai, Y.-S.; Xie, K.; Yu, F.; Wang, C.-J.; Lin, S.-H.; Yang, Y.-Z.; Xu, F. Curcumin Promotes the Expression of IL-35 by Regulating Regulatory T Cell Differentiation and Restrains Uncontrolled Inflammation and Lung Injury in Mice. Inflammation 2020, 43, 1913-1924. [CrossRef]

19. Zhu, H.; Wang, X.; Wang, X.; Liu, B.; Yuan, Y.; Zuo, X. Curcumin attenuates inflammation and cell apoptosis through regulating NF-KB and JAK2/STAT3 signaling pathway against acute kidney injury. Cell Cycle 2020, 19, 1941-1951. [CrossRef]

20. Olszanecki, R.; Jawień, J.; Gajda, M.; Mateuszuk, L.; Gebska, A.; Korabiowska, M.; Chłopicki, S.; Korbut, R. Effect of Curcumin on atherosclerosis in apoE/LDLR-double knockout mice. J. Physiol. Pharmacol. 2005, 56, 627-635.

21. Xie, M.; Tang, Q.; Nie, J.; Zhang, C.; Zhou, X.; Yu, S.; Sun, J.; Cheng, X.; Dong, N.; Hu, Y.; et al. BMAL1-Downregulation Aggravates Porphyromonas Gingivalis-Induced Atherosclerosis by Encouraging Oxidative Stress. Circ. Res. 2020, 126, e15-e29. [CrossRef] [PubMed] 
22. Libby, P.; Ridker, P.M.; Hansson, G.K. Progress and challenges in translating the biology of atherosclerosis. Nature 2011, 473, 317-327. [CrossRef]

23. Kattoor, A.J.; Goel, A.; Mehta, J.L. LOX-1: Regulation, Signaling and Its Role in Atherosclerosis. Antioxidants 2019, 8, 218. [CrossRef]

24. Boonla, O.; Kukongviriyapan, U.; Pakdeechote, P.; Kukongviriyapan, V.; Pannangpetch, P.; Prachaney, P.; Greenwald, S.E. Curcumin improves endothelial dysfunction and vascular remodeling in $2 \mathrm{~K}-1 \mathrm{C}$ hypertensive rats by raising nitric oxide availability and reducing oxidative stress. Nitric Oxide Biol. Chem. 2014, 42, 44-53. [CrossRef]

25. Kapakos, G.; Youreva, V.; Srivastava, A. Cardiovascular protection by curcumin: Molecular aspects. Indian J. Biochem. Biophys. 2012, 49, 306-315. [PubMed]

26. Han, Y.; Sun, H.-J.; Tong, Y.; Chen, Y.-Z.; Ye, C.; Qiu, Y.; Zhang, F.; Chen, A.-D.; Qi, X.-H.; Chen, Q.; et al. Curcumin attenuates migration of vascular smooth muscle cells via inhibiting NFKB-mediated NLRP3 expression in spontaneously hypertensive rats. J. Nutr. Biochem. 2019, 72, 108212. [CrossRef]

27. Horváth, R.; Cerný, J.; Benedík, J.J.; Hökl, J.; Jelínková, I.; Benedík, J. The possible role of human cytomegalovirus (HCMV) in the origin of atherosclerosis. J. Clin. Virol. Off. Publ. Pan Am. Soc. Clin. Virol. 2000, 16, 17-24. [CrossRef]

28. Shen, K.; Xu, L.; Chen, D.; Tang, W.; Huang, Y. Human cytomegalovirus-encoded miR-UL112 contributes to HCMV-mediated vascular diseases by inducing vascular endothelial cell dysfunction. Virus Genes 2018, 54, 172-181. [CrossRef] [PubMed]

29. Lv, Y.-L.; Jia, Y.; Wan, Z.; An, Z.-L.; Yang, S.; Han, F.-F.; Gong, L.-L.; Xuan, L.-L.; Ren, L.-L.; Zhang, W.; et al. Curcumin inhibits the formation of atherosclerosis in ApoE(-/-) mice by suppressing cytomegalovirus activity in endothelial cells. Life Sci. 2020, 257, 117658. [CrossRef]

30. Förstermann, U.; Xia, N.; Li, H. Roles of Vascular Oxidative Stress and Nitric Oxide in the Pathogenesis of Atherosclerosis. Circ. Res. 2017, 120, 713. [CrossRef]

31. Di Pietro, N.; Formoso, G.; Pandolfi, A. Physiology and pathophysiology of oxLDL uptake by vascular wall cells in atherosclerosis. Vasc. Pharmacol. 2016, 84, 1-7. [CrossRef] [PubMed]

32. Ahmed, S.; Khan, H.; Mirzaei, H. Mechanics insights of Curcumin in myocardial ischemia: Where are we standing? Eur. J. Med. Chem. 2019, 183, 111658. [CrossRef] [PubMed]

33. Li, C.; Miao, X.; Li, F.; Adhikari, B.K.; Liu, Y.; Sun, J.; Zhang, R.; Cai, L.; Liu, Q.; Wang, Y. Curcuminoids: Implication for inflammation and oxidative stress in cardiovascular diseases. The clinical studies of Curcumin should be summarized and added in the last chapter. Phytother. Res. 2019, 33, 1-16. [CrossRef]

34. Li, B.; Hu, Y.; Zhao, Y.; Cheng, M.; Qin, H.; Cheng, T.; Wang, Q.; Peng, X.; Zhang, X. Curcumin Attenuates Titanium ParticleInduced Inflammation by Regulating Macrophage Polarization In Vitro and In Vivo. Front. Immunol. 2017, 8, 55. [CrossRef] [PubMed]

35. Momtazi-Borojeni, A.A.; Banach, M.; Majeed, M.; Sahebkar, A. P5330 Evaluating lipid-lowering and anti-atherogenic effect of injectable Curcumin in a rabbit model of atherosclerosis. Eur. Heart J. 2019, 40, ehz746-0299. [CrossRef]

36. Zhou, Z.; Chen, Y.; Wang, F.; Tian, N.; Fan, C. Effect of Curcumin on down-expression of thrombospondin-4 induced by oxidized low-density lipoprotein in mouse macrophages. Biomed. Mater. Eng. 2014, 24, 181-189. [CrossRef]

37. Chen, F.-Y.; Zhou, J.; Guo, N.; Ma, W.-G.; Huang, X.; Wang, H.; Yuan, Z.-Y. Curcumin retunes cholesterol transport homeostasis and inflammation response in M1 macrophage to prevent atherosclerosis. Biochem. Biophys. Res. Commun. 2015, 467, 872-878. [CrossRef] [PubMed]

38. Lin, X.; Liu, M.-H.; Hu, H.-J.; Feng, H.; Fan, X.-J.; Zou, W.; Pan, Y.; Hu, X.; Wang, Z. Curcumin enhanced cholesterol efflux by upregulating ABCA1 expression through AMPK-SIRT1-LXR $\alpha$ signaling in THP-1 macrophage-derived foam cells. DNA Cell Biol. 2015, 34, 561-572. [CrossRef] [PubMed]

39. Karuppagounder, V.; Arumugam, S.; Thandavarayan, R.A.; Sreedhar, R.; Giridharan, V.V.; Afrin, R.; Harima, M.; Miyashita, S.; Hara, M.; Suzuki, K.; et al. Curcumin alleviates renal dysfunction and suppresses inflammation by shifting from M1 to M2 macrophage polarization in daunorubicin induced nephrotoxicity in rats. Cytokine 2016, 84, 1-9. [CrossRef]

40. Gao, S.; Zhou, J.; Liu, N.; Wang, L.; Gao, Q.; Wu, Y.; Zhao, Q.; Liu, P.; Wang, S.; Liu, Y.; et al. Curcumin induces M2 macrophage polarization by secretion IL-4 and/or IL-13. J. Mol. Cell. Cardiol. 2015, 85, 131-139. [CrossRef]

41. Karimian, M.S.; Pirro, M.; Majeed, M.; Sahebkar, A. Curcumin as a natural regulator of monocyte chemoattractant protein-1. Cytokine Growth Factor Rev. 2017, 63, 55-63. [CrossRef] [PubMed]

42. Li, Y.; Tian, L.; Sun, D.; Yin, D. Curcumin ameliorates atherosclerosis through upregulation of miR-126. J. Cell. Physiol. 2019, 234, 21049-21059. [CrossRef] [PubMed]

43. Zhou, Y.; Zhang, T.; Wang, X.; Wei, X.; Chen, Y.; Guo, L.; Zhang, J.; Wang, C. Curcumin Modulates Macrophage Polarization Through the Inhibition of the Toll-Like Receptor 4 Expression and its Signaling Pathways. Cell. Physiol. Biochem. 2015, 36, 631-641. [CrossRef] [PubMed]

44. Jain, S.K.; Rains, J.; Croad, J.; Larson, B.; Jones, K. Curcumin supplementation lowers TNF-alpha, IL-6, IL-8, and MCP-1 secretion in high glucose-treated cultured monocytes and blood levels of TNF-alpha, IL-6, MCP-1, glucose, and glycosylated hemoglobin in diabetic rats. Antioxid. Redox Signal. 2009, 11, 241-249. [CrossRef] [PubMed]

45. Hasan, S.T.; Zingg, J.-M.; Kwan, P.; Noble, T.; Smith, D.; Meydani, M. Curcumin modulation of high fat diet-induced atherosclerosis and steatohepatosis in LDL receptor deficient mice. Atherosclerosis 2014, 232, 40-51. [CrossRef] 
46. Youn, H.S.; Saitoh, S.I.; Miyake, K.; Hwang, D.H. Inhibition of homodimerization of Toll-like receptor 4 by curcumin. Biochem. Pharmacol. 2006, 72, 62-69. [CrossRef]

47. Chen, F.; Guo, N.; Cao, G.; Zhou, J.; Yuan, Z. Molecular analysis of curcumin-induced polarization of murine RAW264.7 macrophages. J. Cardiovasc. Pharmacol. 2014, 63, 544-552. [CrossRef] [PubMed]

48. Wang, J.; Kang, Y.-X.; Pan, W.; Lei, W.; Feng, B.; Wang, X.-J. Enhancement of Anti-Inflammatory Activity of Curcumin Using Phosphatidylserine-Containing Nanoparticles in Cultured Macrophages. Int. J. Mol. Sci. 2016, 17, 969. [CrossRef]

49. Ouyang, S.; Yao, Y.-H.; Zhang, Z.-M.; Liu, J.-S.; Xiang, H. Curcumin inhibits hypoxia inducible factor-1 $\alpha$-induced inflammation and apoptosis in macrophages through an ERK dependent pathway. Eur. Rev. Med. Pharmacol. Sci. 2019, 23, 1816-1825. [CrossRef]

50. Keshavarz, Z.; Kheirollah, A.; Ghaffari, M.-A.; Babaahmadi-Rezaei, H. Curcumin Inhibited Endothelin-1 mRNA Expression Induced by TGF- $\beta$ in Bovine Aortic Endothelial Cell. Jundishapur J. Nat. Pharm. Prod. 2019, 14. [CrossRef]

51. Ameruoso, A.; Palomba, R.; Palange, A.L.; Cervadoro, A.; Lee, A.; Di Mascolo, D.; Decuzzi, P. Ameliorating Amyloid- $\beta$ Fibrils Triggered Inflammation via Curcumin-Loaded Polymeric Nanoconstructs. Front. Immunol. 2017, 8, 1411. [CrossRef]

52. Cao, J.; Ye, B.; Lin, L.; Tian, L.; Yang, H.; Wang, C.; Huang, W.; Huang, Z. Curcumin Alleviates oxLDL Induced MMP-9 and EMMPRIN Expression through the Inhibition of NF-kB and MAPK Pathways in Macrophages. Front. Pharmacol. $2017,8,62$. [CrossRef]

53. Cao, J.; Han, Z.; Tian, L.; Chen, K.; Fan, Y.; Ye, B.; Huang, W.; Wang, C.; Huang, Z. Curcumin inhibits EMMPRIN and MMP-9 expression through AMPK-MAPK and PKC signaling in PMA induced macrophages. J. Transl. Med. 2014, 12, 266. [CrossRef] [PubMed]

54. Huang, S.-L.; Chen, P.-Y.; Wu, M.-J.; Tai, M.-H.; Ho, C.-T.; Yen, J.-H. Curcuminoids Modulate the PKC $/$ NADPH Oxidase/Reactive Oxygen Species Signaling Pathway and Suppress Matrix Invasion during Monocyte-Macrophage Differentiation. J. Agric. Food Chem. 2015, 63, 8838-8848. [CrossRef]

55. Kong, F.; Ye, B.; Cao, J.; Cai, X.; Lin, L.; Huang, S.; Huang, W.; Huang, Z. Curcumin Represses NLRP3 Inflammasome Activation via TLR4/MyD88/NF-kB and P2X7R Signaling in PMA-Induced Macrophages. Front. Pharmacol. 2016, 7, 369. [CrossRef] [PubMed]

56. Zheng, L.; Sun, X.; Zhu, X.; Lv, F.; Zhong, Z.; Zhang, F.; Guo, W.; Cao, W.; Yang, L.; Tian, Y. Apoptosis of THP-1 derived macrophages induced by sonodynamic therapy using a new sonosensitizer hydroxyl acetylated curcumin. PLoS ONE 2014, 9, e93133. [CrossRef] [PubMed]

57. Zhong, Y.; Liu, T.; Guo, Z. Curcumin inhibits ox-LDL-induced MCP-1 expression by suppressing the p38MAPK and NF- $\mathrm{B}$ pathways in rat vascular smooth muscle cells. Inflamm. Res. Off. J. Eur. Histamine Res. Soc. 2012, 61, 61-67. [CrossRef]

58. Hosseinzadeh, L.; Behravan, J.; Mosaffa, F.; Bahrami, G.; Bahrami, A.; Karimi, G. Curcumin potentiates doxorubicin-induced apoptosis in $\mathrm{H} 9 \mathrm{c} 2$ cardiac muscle cells through generation of reactive oxygen species. Food Chem. Toxicol. Int. J. Publ. Br. Ind. Biol. Res. Assoc. 2011, 49, 1102-1109. [CrossRef]

59. Meng, Z.; Yan, C.; Deng, Q.; Gao, D.; Niu, X. Curcumin inhibits LPS-induced inflammation in rat vascular smooth muscle cells in vitro via ROS-relative TLR4-MAPK/NF-кB pathways. Acta Pharmacol. Sin. 2013, 34, 901-911. [CrossRef]

60. Liu, T.; Li, C.; Sun, H.; Luo, T.; Tan, Y.; Tian, D.; Guo, Z. Curcumin inhibits monocyte chemoattractant protein-1 expression and enhances cholesterol efflux by suppressing the c-Jun N-terminal kinase pathway in macrophage. Inflamm. Res. Off. J. Eur. Histamine Res. Soc. 2014, 63, 841-850. [CrossRef]

61. Ahn, J.; Lee, H.; Kim, S.; Ha, T. Curcumin-induced suppression of adipogenic differentiation is accompanied by activation of Wnt/beta-catenin signaling. Am. J. Physiol. Cell Physiol. 2010, 298, C1510-6. [CrossRef] [PubMed]

62. Zhang, X.; Liu, J.; Pang, X.; Zhao, J.; Xu, S. Curcumin Suppresses Aldosterone-Induced CRP Generation in Rat Vascular Smooth Muscle Cells via Interfering with the ROS-ERK1/2 Signaling Pathway. Evid. Based. Complement. Altern. Med. 2020, 2020, 3245653. [CrossRef]

63. Wu, T.; Xiang, Y.; Lv, Y.; Li, D.; Yu, L.; Guo, R. miR-590-3p mediates the protective effect of Curcumin on injured endothelial cells induced by angiotensin II. Am. J. Transl. Res. 2017, 9, 289-300. [PubMed]

64. Ramaswami, G.; Chai, H.; Yao, Q.; Lin, P.H.; Lumsden, A.B.; Chen, C. Curcumin blocks homocysteine-induced endothelial dysfunction in porcine coronary arteries. J. Vasc. Surg. 2004, 40, 1216-1222. [CrossRef] [PubMed]

65. Montiel-Dávalos, A.; Silva Sánchez, G.J.; Huerta-García, E.; Rueda-Romero, C.; Soca Chafre, G.; Mitre-Aguilar, I.B.; Alfaro-Moreno, E.; Pedraza-Chaverri, J.; López-Marure, R. Curcumin inhibits activation induced by urban particulate material or titanium dioxide nanoparticles in primary human endothelial cells. PLoS ONE 2017, 12, e0188169. [CrossRef]

66. Lee, S.E.; Park, H.R.; Jeon, S.; Han, D.; Park, Y.S. Curcumin Attenuates Acrolein-induced COX-2 Expression and Prostaglandin Production in Human Umbilical Vein Endothelial Cells. J. Lipid Atheroscler. 2020, 9, 184-194. [CrossRef]

67. Lee, H.-S.; Lee, M.-J.; Kim, H.; Choi, S.-K.; Kim, J.-E.; Moon, H.-I.; Park, W.-H. Curcumin inhibits TNFalpha-induced lectin-like oxidised LDL receptor-1 (LOX-1) expression and suppresses the inflammatory response in human umbilical vein endothelial cells (HUVECs) by an antioxidant mechanism. J. Enzym. Inhib. Med. Chem. 2010, 25, 720-729. [CrossRef]

68. Kim, D.-C.; Ku, S.-K.; Lee, W.; Bae, J.-S. Barrier protective activities of Curcumin and its derivative. Inflamm. Res. Off. J. Eur. Histamine Res. Soc. 2012, 61, 437-444. [CrossRef]

69. Kim, Y.S.; Ahn, Y.; Hong, M.H.; Joo, S.Y.; Kim, K.H.; Sohn, I.S.; Park, H.W.; Hong, Y.J.; Kim, J.H.; Kim, W.; et al. Curcumin attenuates inflammatory responses of TNF-alpha-stimulated human endothelial cells. J. Cardiovasc. Pharmacol. 2007, 50, 41-49. [CrossRef] 
70. Zhong, Y.; Feng, J.; Li, J.; Fan, Z. Curcumin prevents lipopolysaccharide-induced matrix metalloproteinase-2 activity via the Ras/MEK1/2 signaling pathway in rat vascular smooth muscle cells. Mol. Med. Rep. 2017, 16, 4315-4319. [CrossRef]

71. Zhang, M.; Li, Y.; Xie, H.; Chen, J.; Liu, S. Curcumin inhibits proliferation, migration and neointimal formation of vascular smooth muscle via activating miR-22. Pharm. Biol. 2020, 58, 610-619. [CrossRef]

72. Yuan, H.-Y.; Kuang, S.-Y.; Zheng, X.; Ling, H.-Y.; Yang, Y.-B.; Yan, P.-K.; Li, K.; Liao, D.-F. Curcumin inhibits cellular cholesterol accumulation by regulating SREBP-1/caveolin-1 signaling pathway in vascular smooth muscle cells. Acta Pharmacol. Sin. 2008, 29, 555-563. [CrossRef]

73. Den Dekker, W.K.; Cheng, C.; Pasterkamp, G.; Duckers, H.J. Toll like receptor 4 in atherosclerosis and plaque destabilization. Atherosclerosis 2010, 209, 314-320. [CrossRef] [PubMed]

74. Kim, K.-H.; Lee, E.N.; Park, J.K.; Lee, J.-R.; Kim, J.-H.; Choi, H.-J.; Kim, B.-S.; Lee, H.-W.; Lee, K.-S.; Yoon, S. Curcumin attenuates TNF- $\alpha$-induced expression of intercellular adhesion molecule-1, vascular cell adhesion molecule- 1 and proinflammatory cytokines in human endometriotic stromal cells. Phytother. Res. 2012, 26, 1037-1047. [CrossRef]

75. Latz, E.; Xiao, T.S.; Stutz, A. Activation and regulation of the inflammasomes. Nat. Rev. Immunol. 2013, 13, 397-411. [CrossRef] [PubMed]

76. Tian, K.; Ogura, S.; Little, P.J.; Xu, S.; Sawamura, T. Targeting LOX-1 in atherosclerosis and vasculopathy: Current knowledge and future perspectives. Ann. N.Y. Acad. Sci. 2019, 1443, 34-53. [CrossRef] [PubMed]

77. Min, K.; Um, H.J.; Cho, K.-H.; Kwon, T.K. Curcumin inhibits oxLDL-induced CD36 expression and foam cell formation through the inhibition of p38 MAPK phosphorylation. Food Chem. Toxicol. Int. J. Publ. Br. Ind. Biol. Res. Assoc. 2013, 58, 77-85. [CrossRef]

78. Tontonoz, P.; Nagy, L.; Alvarez, J.G.A.; Thomazy, V.A.; Evans, R.M. PPAR $\gamma$ Promotes Monocyte/Macrophage Differentiation and Uptake of Oxidized LDL. Cell 1998, 93, 241-252. [CrossRef]

79. Chistiakov, D.A.; Bobryshev, Y.V.; Orekhov, A.N. Macrophage-mediated cholesterol handling in atherosclerosis. J. Cell. Mol. Med. 2016, 20, 17-28. [CrossRef]

80. Makowski, L.; Brittingham, K.C.; Reynolds, J.M.; Suttles, J.; Hotamisligil, G.S. The fatty acid-binding protein, aP2, coordinates macrophage cholesterol trafficking and inflammatory activity. Macrophage expression of aP2 impacts peroxisome proliferatoractivated receptor gamma and IkappaB kinase activities. J. Biol. Chem. 2005, 280, 12888-12895. [CrossRef]

81. Wessel, J.; Topol, E.J.; Ji, M.; Meyer, J.; McCarthy, J.J. Replication of the association between the thrombospondin-4 A387P polymorphism and myocardial infarction. Am. Heart J. 2004, 147, 905-909.

82. Changal, K.H.; Khan, M.S.; Bashir, R.; Sheikh, M.A. Curcumin Preparations Can Improve Flow-Mediated Dilation and Endothelial Function: A Meta-Analysis. Complement. Med. Res. 2020, 27, 272-281. [CrossRef]

83. Li, X.; Lu, Y.; Sun, Y.; Zhang, Q. Effect of Curcumin on permeability of coronary artery and expression of related proteins in rat coronary atherosclerosis heart disease model. Int. J. Clin. Exp. Pathol. 2015, 8, 7247-7253.

84. Gao, S.; Zhang, W.; Zhao, Q.; Zhou, J.; Wu, Y.; Liu, Y.; Yuan, Z.; Wang, L. Curcumin ameliorates atherosclerosis in apolipoprotein E deficient asthmatic mice by regulating the balance of Th2/Treg cells. Phytomedicine 2019, 52, 129-135. [CrossRef] [PubMed]

85. Majeed, M.L.; Ghafil, F.A.; Fatima, G.; Hadi, N.R.; Mahdi, H.F. Anti-Atherosclerotic and Anti-Inflammatory Effects of Curcumin on Hypercholesterolemic Male Rabbits. Indian J. Clin. Biochem. 2021, 36, 74-80. [CrossRef]

86. Amato, A.; Caldara, G.F.; Nuzzo, D.; Baldassano, S.; Picone, P.; Rizzo, M.; Mulè, F.; Di Carlo, M. NAFLD and atherosclerosis are prevented by a natural dietary supplement containing curcumin, silymarin, guggul, chlorogenic acid and inulin in mice fed a high-fat diet. Nutrients 2017, 9, 492. [CrossRef] [PubMed]

87. Coban, D.; Milenkovic, D.; Chanet, A.; Khallou-Laschet, J.; Sabbe, L.; Palagani, A.; Vanden Berghe, W.; Mazur, A.; Morand, C. Dietary curcumin inhibits atherosclerosis by affecting the expression of genes involved in leukocyte adhesion and transendothelial migration. Mol. Nutr. Food Res. 2012, 56, 1270-1281. [CrossRef]

88. Ghosh, S.S.; Bie, J.; Wang, J.; Ghosh, S. Oral supplementation with non-absorbable antibiotics or Curcumin attenuates western dietinduced atherosclerosis and glucose intolerance in LDLR - / - mice-role of intestinal permeability and macrophage activation. PLoS ONE 2014, 9, e108577. [CrossRef]

89. Pan, Y.; Wang, Y.; Cai, L.; Cai, Y.; Hu, J.; Yu, C.; Li, J.; Feng, Z.; Yang, S.; Li, X.; et al. Inhibition of high glucose-induced inflammatory response and macrophage infiltration by a novel Curcumin derivative prevents renal injury in diabetic rats. $B r$. $J$. Pharmacol. 2012, 166, 1169-1182. [CrossRef]

90. Jin, S.; Hong, J.H.; Jung, S.H.; Cho, K.H. Turmeric and laurel aqueous extracts exhibit in vitro anti-atherosclerotic activity and in vivo hypolipidemic effects in a zebrafish model. J. Med. Food 2011, 14, 247-256. [CrossRef]

91. Shin, S.K.; Ha, T.Y.; McGregor, R.A.; Choi, M.S. Long-term Curcumin administration protects against atherosclerosis via hepatic regulation of lipoprotein cholesterol metabolism. Mol. Nutr. Food Res. 2011, 55, 1829-1840. [CrossRef] [PubMed]

92. Wan, Q.; Liu, Z.Y.; Yang, Y.P.; Liu, S.M. Effect of Curcumin on inhibiting atherogenesis by down-regulating lipocalin-2 expression in apolipoprotein E knockout mice. Bio-Med. Mater. Eng. 2016, 27, 577-587. [CrossRef]

93. Zheng, B.; Yang, L.; Wen, C.; Huang, X.; Xu, C.; Lee, K.H.; Xu, J. Curcumin analog L3 alleviates diabetic atherosclerosis by multiple effects. Eur. J. Pharmacol. 2016, 775, 22-34. [CrossRef]

94. Zou, J.; Zhang, S.; Li, P.; Zheng, X.; Feng, D. Supplementation with Curcumin inhibits intestinal cholesterol absorption and prevents atherosclerosis in high-fat diet-fed apolipoprotein E knockout mice. Nutr. Res. 2018, 56, 32-40. [CrossRef] [PubMed]

95. Panahi, Y.; Khalili, N.; Sahebi, E.; Namazi, S.; Reiner, Ž.; Majeed, M.; Sahebkar, A. Curcuminoids modify lipid profile in type 2 diabetes mellitus: A randomized controlled trial. Complementary Ther. Med. 2017, 33, 1-5. [CrossRef] [PubMed] 
96. Panahi, Y.; Kianpour, P.; Mohtashami, R.; Jafari, R.; Simental-Mendía, L.E.; Sahebkar, A. Curcumin lowers serum lipids and uric acid in subjects with nonalcoholic fatty liver disease: A randomized controlled trial. J. Cardiovasc. Pharmacol. 2016, 68, 223-229. [CrossRef]

97. Ramırez-Boscá, A.; Soler, A.; Carrion, M.A.; Diaz-Alperi, J.; Bernd, A.; Quintanilla, C.; Almagro, E.Q.; Miquel, J. An hydroalcoholic extract of Curcuma longa lowers the apo B/apo A ratio: Implications for atherogenesis prevention. Mech. Ageing Dev. 2000, 119, 41-47. [CrossRef]

98. Wongcharoen, W.; Jai-Aue, S.; Phrommintikul, A.; Nawarawong, W.; Woragidpoonpol, S.; Tepsuwan, T.; Sukonthasarn, A.; Apaijai, N.; Chattipakorn, N. Effects of curcuminoids on frequency of acute myocardial infarction after coronary artery bypass grafting. Am. J. Cardiol. 2012, 110, 40-44. [CrossRef] [PubMed]

99. Funamoto, M.; Sunagawa, Y.; Katanasaka, Y.; Miyazaki, Y.; Imaizumi, A.; Kakeya, H.; Yamakage, H.; Satoh-Asahara, N.; Komiyama, M.; Wada, H.; et al. Highly absorptive Curcumin reduces serum atherosclerotic low-density lipoprotein levels in patients with mild COPD. Int. J. Chronic Obstr. Pulm. Dis. 2016, 11, 2029.

100. DiSilvestro, R.A.; Joseph, E.; Zhao, S.; Bomser, J. Diverse effects of a low dose supplement of lipidated Curcumin in healthy middle aged people. Nutr. J. 2012, 11, 1-8. [CrossRef]

101. Oliver, J.M.; Stoner, L.; Rowlands, D.S.; Caldwell, A.R.; Sanders, E.; Kreutzer, A.; Mitchell, J.B.; Purpura, M.; Jäger, R. Novel form of Curcumin improves endothelial function in young, healthy individuals: A double-blind placebo controlled study. J. Nutr. Metab. 2016, 2016, 1089653. [CrossRef]

102. Campbell, M.S.; Berrones, A.J.; Krishnakumar, I.M.; Charnigo, R.J.; Westgate, P.M.; Fleenor, B.S. Responsiveness to Curcumin intervention is associated with reduced aortic stiffness in young, obese men with higher initial stiffness. J. Funct. Foods 2017, 29, 154-160. [CrossRef]

103. Zhou, Y.; Little, P.J.; Xu, S.; Kamato, D. Curcumin Inhibits Lysophosphatidic Acid Mediated MCP-1 Expression via Blocking ROCK Signalling. Molecules 2021, 26, 2320. [CrossRef] [PubMed]

104. Helli, B.; Gerami, H.; Kavianpour, M.; Heybar, H.; Hosseini, S.K.; Haghighian, H.K. Curcumin Nanomicelle Improves Lipid Profile, Stress Oxidative Factors and Inflammatory Markers in Patients Undergoing Coronary Elective Angioplasty; A Randomized Clinical Trial. Endocr. Metab. Immune Disord. Drug Targets 2021. [CrossRef] [PubMed]

105. Li, L.; Zhang, X.; Pi, C.; Yang, H.; Zheng, X.; Zhao, L.; Wei, Y. Review of Curcumin Physicochemical Targeting Delivery System. Int. J. Nanomed. 2020, 15, 9799-9821. [CrossRef]

106. Pechanova, O.; Dayar, E.; Cebova, M. Therapeutic Potential of Polyphenols-Loaded Polymeric Nanoparticles in Cardiovascular System. Molecules 2020, 25, 3322. [CrossRef] [PubMed] 